\title{
Effects of Nitrogen Fertilization and Frequency of Cutting on the Yield and Composition of Para Grass in Puerto Rico ${ }^{1}$
}

\author{
José Vicente-Chandler, Servando Silva, and Jacinto Figarella ${ }^{2}$
}

\section{INTRODUCTION}

Para grass (Panicum purpurascens) (fig. 1) is one of the most widely used forage grasses of the humid Tropics, thriving wherever there is abundant rainfall and adequate soil fertility. This grass is adapted both to grazing and cutting and, in Puerto Rico, is usually grown on valuable land where it is essential that high yields be obtained.

Little is known regarding the effects of nitrogen fertilizer or frequency of cutting on yield and composition of this grass. Rivera-Brenes $(1)^{3}$ in Puerto Rico, reported that Para grass yielded slightly more when cut at 90-day intervals and less when cut at 120-day intervals than when harvested every 40 days, and that the lignin content increased while the protein content decreased with length of harvest interval, while Rodriguez (2) found that the application of 200 pounds of nitrogen per acre yearly about doubled the yields of this grass.

This paper presents results of an experiment carried out to characterize the response of Para grass to nitrogen fertilization as affected by frequency of cutting and season of the year. The effects of treatments on forage composition were also studied.

\section{MATERIALS AND METHODS}

The experiment was carried out at Rio Piedras over a full year period with a total of 95.1 inches of rainfall. The mean annual temperature is about $76^{\circ} \mathrm{F}$., with seasonal variations of less than $10^{\circ} \mathrm{F}$.

The soil is a Fajardo clay, a deep, fairly well-drained soil, on about a 20percent slope. Initially, the surface 6 inches averaged 3.2 percent of organic matter, 0.17 percent of nitrogen, 12.1 m.e. exchange capacity, and 6.0 m.e. of exchangeable bases per $100 \mathrm{gm}$. of soil, and had a $\mathrm{pH} 4.8$. The treatments used were as follows:

1 This work was carried out cooperatively between the U. S. Department of Agriculture and the Agricultural Experiment Station of the University of Puerto Rico.

${ }^{2}$ Project Supervisor, Physical Science Aid, and Soil Scientist, respectively, Soil and Water Conservation Research Division, Agricultural Research Service, U. S. Department of Agriculture.

${ }^{3}$ Italic numbers in parentheses refer to Literature Cited, p. 248. 
IIarvest interrals
(Days)

40

60

90
Nitrogen lezels

(Pounds $N$ per acre yearly)

0

200

400

800

1,600

All combinations of these treatments were tested using a split-plot design with harvest intervals as the main plots and nitrogen levels as the

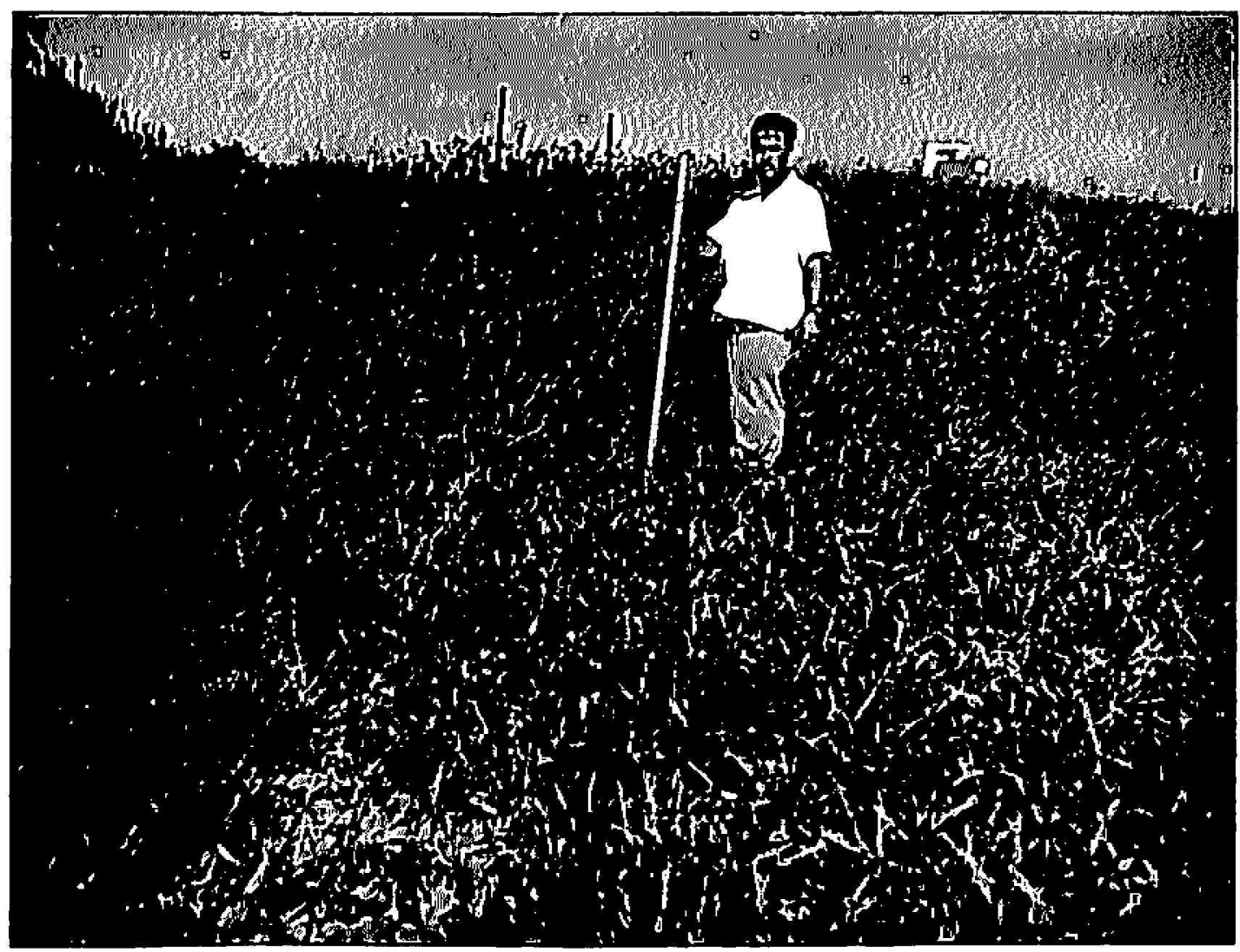

FIG. 1.-Para grass fifty days after cutting showing response to nitrogen fertilization. Plot in foreground received 200 pounds of nitrogen per acre yearly while that in background received 800 pounds.

subplots. All treatments were replicated four times. Subplots were $10 \times 20$ feet surrounded by ditches to prevent fertilizer from washing into adjoining plots.

The upper 6 inches of soil in all plots was limed to a $\mathrm{pH}$ of about 6.5 at the start of the experiment. Blanket additions of phosphorus and potassium were made at the rate of 300 pounds $\mathrm{P}_{2} \mathrm{O}_{5}$ per acre from 20-percent superphosphate in one application and 600 pounds $\mathrm{K}_{2} \mathrm{O}$ from $\mathrm{KCl}$ per acre annually in four to nine equal applications, depending on frequency of cutting. The nitrogen was applied as ammonium sulfate in four to nine equal applications yearly, depending on frequency of cutting. 
The grass was cut at the prescribed intervals, weighed, and the forage removed from the plots. Samples from each plot at every harvest were analyzed for dry matter and total nitrogen. The crude-protein content was calculated using the factor 6.25 times $\mathrm{X}$. Samples were composited

TABLE 1.-The effects of nitrogen ferlilization and frequency of cutting on the yield and protein content of Para grass and on the efficiency of utilization of the applied nitrogen over a 1-year period

\begin{tabular}{|c|c|c|c|c|c|c|}
\hline $\begin{array}{c}\text { Nitrogen } \\
\text { applied per acre } \\
\text { yearly }\end{array}$ & $\begin{array}{l}\text { Yicld of green } \\
\text { forage per acre } \\
\text { yearly }\end{array}$ & $\begin{array}{c}\text { Yield of dry } \\
\text { matter per acre } \\
\text { yearly }\end{array}$ & $\begin{array}{l}\text { Crude-pro- } \\
\text { tein content }\end{array}$ & $\begin{array}{l}\text { Crude-protein } \\
\text { yield per acre } \\
\text { yearly }\end{array}$ & $\begin{array}{l}\text { Recovery of } \\
\mathbf{N} \text { in forage }\end{array}$ & $\begin{array}{l}\text { Dry matter } \\
\text { produced per } \\
\text { pound of each } \\
\text { increment of } \\
\mathbf{N}\end{array}$ \\
\hline
\end{tabular}

Grass cul every 40 days

\begin{tabular}{|c|c|c|c|c|c|c|}
\hline$L b$. & $L b$. & $L b$. & Percent & Lb. & Percent & $L b$. \\
\hline & 22,523 & 5,156 & 7.3 & 378 & - & 一 \\
\hline 200 & 54,758 & 11,624 & 8.1 & 943 & 45.2 & 32.3 \\
\hline 400 & 83,066 & 17,109 & 9.2 & 1,576 & 47.7 & 27.4 \\
\hline 800 & 120,117 & 23,607 & 11.7 & 2,759 & 47.6 & 16.2 \\
\hline 1,600 & 133,094 & 25,444 & 15.0 & 3,807 & 34.3 & 2.3 \\
\hline \multicolumn{7}{|c|}{ Grass cut every 60 days } \\
\hline 0 & 31,919 & 7,805 & 6.4 & 498 & - & - \\
\hline 200 & 74,223 & 17,616 & 6.3 & 1,115 & 49.5 & 49.1 \\
\hline 400 & 101,574 & 23,832 & 7.2 & 1,716 & 48.8 & 31.1 \\
\hline 800 & 139,635 & 30,841 & 9.5 & 2,937 & 47.8 & 17.5 \\
\hline 1,600 & 157,635 & 32,579 & 12.1 & 3,949 & 34.5 & 2.2 \\
\hline \multicolumn{7}{|c|}{ Grass cut every 90 days } \\
\hline 0 & 42,468 & 13,070 & 4.8 & 626 & - & - \\
\hline 200 & 76,181 & 22,734 & 4.3 & 987 & 29.0 & 48.3 \\
\hline 400 & 104,673 & 32,910 & 4.8 & 1,592 & 38.7 & 50.9 \\
\hline 800 & 128,598 & 36,294 & 7.2 & 2,615 & 39.8 & 8.4 \\
\hline 1,600 & 143,442 & 39,189 & 8.9 & 3,471 & 28.4 & 3.6 \\
\hline
\end{tabular}

by plots at the end of the year and analyzed for calcium, phosphorus, potassium, magnesium, and lignin.

\section{RESULTS}

\section{EFFECT OF LENGTH OF HARVEST INTERVAL}

The data in table 1 and figure 2 show that yields increased markedly with length of harvest interval. At the 800-pound level of nitrogen, Para grass produced $23,607,30,841$, and 36,294 pounds of dry matter per acre 
yearly when cut at 40-, 60-, and 90-day intervals, respectively. The drymatter content of the forage also increased with the harvest interval averaging $20.7,22.9$, and 29.5 percent, with the $40-, 60$-, and 90 -day harvest intervals, respectively.

The protein content of the forage, however, dropped with each increase in harvest interval, averaging at the 800-pound level of nitrogen, 11.7, 9.5 , and 7.2 percent when the grass was cut every 40,60 , and 90 days, respectively. Frequency of cutting had little effect on protein yields, however.

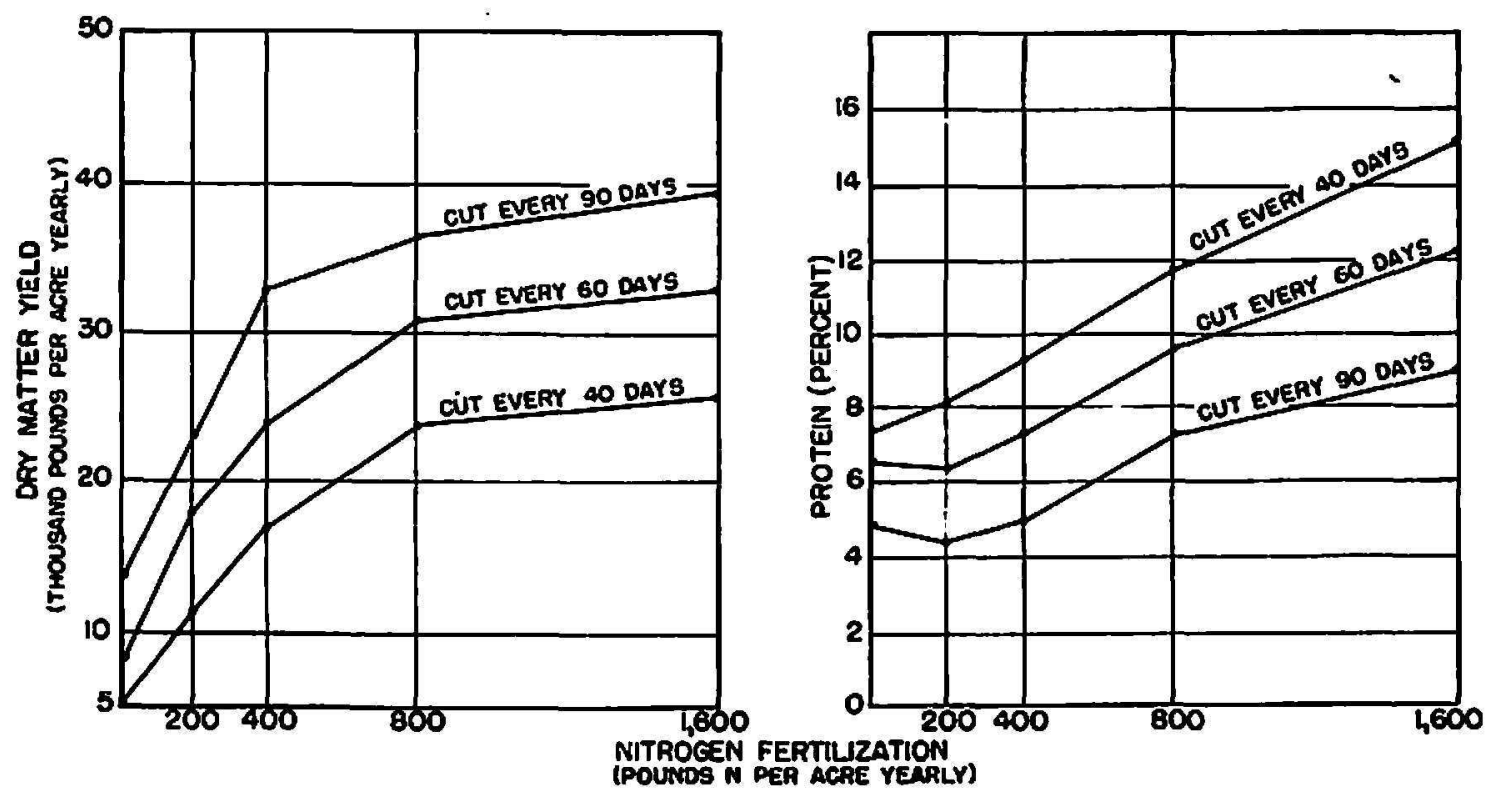

Fig. 2.-Effects of nitrogen fertilization and frequency of cutting on yield and protein content of Para grass.

A lower proportion of the applied nitrogen was recovered in the forage when the grass was cut every 90 days than with the shorter harvest intervals.

The data in table 2 show that the phosphorus, calcium, potassium, and magnesium contents of the forage decreased significantly while lignin content increased with length of harvest interval.

\section{EFFECT OF NITROGEN FERTILIZATION}

The data in table 1 and figure 2 show that yields increased rapidly with nitrogen fertilization up to the 800-pound level (fig. 1). With a 60-day harvest interval, yields were about quadrupled, attaining 30,841 pounds of dry matter per acre yearly, by the application of 800 pounds of nitrogen. A detailed analysis of the data shows that yields increased with nitrogen fertilization up to the 400-pound level, even during dry seasons of slow growth. Whenever weather was favorable, a strong response in yield was 
evident up to the 800-pound level of nitrogen. When nitrogen at the rate of 800 pounds per acre yearly was applied during dry weather, considerable burning and loss of stand was evident. This effect was very serious at the 1,600-pound level of nitrogen.

The protein content of the forage increased with nitrogen rates up to the highest level tested, averaging when cut every 60 days, 6.4, 7.2, 9.5, and 12.1 when fertilized with $0,400,800$, and 1,600 pounds of nitrogen per acre yearly, respectively. Forage containing 15 percent of protein was obtained when Para grass was cut every 40 days and fertilized with 1,600 pounds of nitrogen per acre yearly. The assumption is made that the nitrogen was essentially all in amino form since no more than traces of nitrates were found in the forage.

Protein yields increased rapidly with nitrogen fertilization up to the maximum level tested, averaging with a 60-day harvest interval, 498, $1,716,2,937$, and 3,949 pounds per acre yearly, at the $0-, 400-, 800-$, and 1,600 -pound levels of nitrogen, respectively.

The data in table 1 show that, with a 60-day harvest interval, about half of the applied nitrogen was recovered in the forage when 800 pounds or less were applied per acre yearly, compared to about 35 percent at the 1,600-pound rate. Para grass obtained about 80 pounds of nitrogen from the soil when none was applied as fertilizer.

The efficiency of utilization of fertilizer nitrogen decreased rapidly with increasing rates. With a 60-day harvest interval, 49.1, 31.1, 17.5, and 2.2 pounds of dry matter were produced per pound of each successive increment of nitrogen.

The data in table 2 show that the phosphorus content of the forage decreased significantly with increased nitrogen fertilization, averaging $0.27,0.20$, and 0.17 percent at the $0-, 400$-, and 800 -pound levels of nitrogen, respectively. Nitrogen fertilization had no strong effect on the calcium, potassium, or magnesium contents of the forage. The lignin content of the forage, however, increased with nitrogen rates averaging $7.77,8.44$, and 9.02 percent at the $0-, 400-$, and 800 -pound rates of nitrogen.

Proper fertilization with nitrogen helped reduce weeds.

\section{NUTRIENT WITHDRAWAL AT HIGH YIELD LEVELS}

Table 2 shows that intensively managed Para grass withdraws large amounts of nutrients, particularly nitrogen and potassium. With a 60-day harvest interval and an 800-pound rate of nitrogen, about 52 pounds of phosphorus, 120 pounds of calcium, 77 pounds of magnesium, 469 pounds of nitrogen, and 524 pounds of potassium were removed per acre yearly in the forage. It follows that heavy fertilization is required to sustain high yields.

Nutrient withdrawal increased greatly with nitrogen rates but was not 
TABLE 2.-The effects of nitrogen fertitization and harvest interval on the mineral and lignin contents of Para grass and on withdrawal of nutrients in forage

\begin{tabular}{|c|c|c|c|c|c|c|c|c|}
\hline \multirow{3}{*}{$\begin{array}{l}\text { Nitrogen fertilization } \\
\text { (pounds N per acre } \\
\text { yearly) }\end{array}$} & \multicolumn{8}{|c|}{ Results at harvest intervals indicated } \\
\hline & \multicolumn{2}{|c|}{40 days } & \multicolumn{2}{|c|}{60 days } & \multicolumn{2}{|c|}{90 days } & \multicolumn{2}{|c|}{ Average } \\
\hline & $\begin{array}{l}\text { Percent- } \\
\text { age com- } \\
\text { position }\end{array}$ & $\begin{array}{c}\text { Pounds } \\
\text { withdrawn } \\
\text { per acre } \\
\text { yearly }\end{array}$ & $\begin{array}{l}\text { Percent- } \\
\text { age com- } \\
\text { position }\end{array} \mid$ & $\begin{array}{c}\text { Pounds } \\
\text { withdrawn } \\
\text { per acre } \\
\text { yearly }\end{array}$ & $\begin{array}{l}\text { Percent- } \\
\text { age com- } \\
\text { position }\end{array}$ & $\begin{array}{c}\text { Pounds } \\
\text { withdrawn } \\
\text { per acre } \\
\text { yearly }\end{array}$ & $\mid \begin{array}{l}\text { Percent- } \\
\text { age com- } \\
\text { position }\end{array}$ & $\begin{array}{c}\text { Pounds } \\
\text { withdrawn } \\
\text { per acre } \\
\text { yearly }\end{array}$ \\
\hline \multicolumn{9}{|c|}{ Nitrogen } \\
\hline 0 & 1.17 & 60.3 & 1.02 & 79.6 & 0.77 & 100.6 & 0.98 & 80.2 \\
\hline 400 & 1.47 & 251.5 & 1.15 & 274.1 & .77 & 253.5 & 1.13 & 259.7 \\
\hline 800 & 1.87 & 441.5 & 1.52 & 468.8 & 1.15 & 417.4 & 1.51 & 442.5 \\
\hline Average & 1.50 & 251.1 & 1.23 & 274.2 & 0.89 & 257.2 & & \\
\hline \multicolumn{9}{|c|}{ Phosphorus } \\
\hline 0 & 0.30 & 15.5 & 0.28 & 21.8 & 0.23 & 30.1 & 0.27 & 22.5 \\
\hline 400 & .25 & 42.8 & .21 & 50.1 & .15 & 49.4 & .20 & 47.4 \\
\hline 800 & .19 & 44.8 & .17 & 52.4 & .14 & 50.8 & .17 & 49.4 \\
\hline Average & 0.25 & 34.4 & 0.22 & 41.4 & 0.17 & 43.4 & & \\
\hline
\end{tabular}

Calcium

\begin{tabular}{r|r|r|r|r|r|r|r|r}
\hline 0 & 0.37 & 19.1 & 0.29 & 22.6 & 0.26 & 34.0 & 0.31 & 45.7 \\
400 & .39 & 66.7 & .35 & 83.4 & .29 & 95.5 & .34 & 81.9 \\
800 & .44 & 103.8 & .39 & 120.3 & .34 & 123.4 & .39 & 115.8 \\
\cline { 2 - 7 } Average & 0.40 & 63.2 & 0.34 & 75.4 & 0.30 & 84.3 & & \\
\hline
\end{tabular}

Potassium

\begin{tabular}{r|r|r|r|r|r|r|r|r}
\hline 0 & 1.77 & 91.3 & 1.64 & 128.0 & 1.12 & 146.4 & 1.51 & 121.9 \\
400 & 2.21 & 378.1 & 1.75 & 417.1 & 1.00 & 329.2 & 1.65 & 274.8 \\
800 & 1.84 & 434.4 & 1.70 & 524.3 & 1.40 & 508.1 & 1.64 & 448.9 \\
\cline { 2 - 7 } Average & 1.94 & 301.2 & 1.70 & 356.5 & 1.17 & 327.9 & & \\
\hline
\end{tabular}

Magnesium

\begin{tabular}{r|r|r|r|r|r|r|r|r}
\hline 0 & 0.26 & 13.4 & 0.16 & 12.5 & 0.11 & 14.4 & 0.18 & 13.4 \\
400 & .27 & 46.2 & .20 & 47.7 & .15 & 49.4 & .21 & 47.7 \\
800 & .34 & 80.3 & .25 & 77.1 & .23 & 83.5 & .27 & 80.3 \\
\cline { 2 - 8 } Average & 0.29 & 46.6 & 0.20 & 45.8 & 0.16 & 49.1 & & \\
\hline
\end{tabular}

Lignin

\begin{tabular}{r|r|r|r|r|r|r|r|r}
\hline 0 & 7.49 & - & 7.42 & - & 8.40 & - & 7.77 & - \\
800 & 7.53 & - & 8.41 & - & 9.39 & - & 8.44 & - \\
800 & 8.22 & - & 8.95 & - & 9.88 & - & 9.02 & - \\
\hline & 7.75 & - & 9.26 & - & 9.22 & - & - & - \\
\hline
\end{tabular}

${ }^{1}$ All values are averages of 4 replicates composited from all cuttings over a full 1-year period.

2 On dry-weight basis. 
strongly affected by frequency of cutting. Withdrawal of phosphorus was about doubled, of calcium about quintupled, of potassium about quadrupled, of magnesium about sextupled, and of nitrogen about quintupled when nitrogen rates were raised from 0 to 800 pounds per acre yearly with a 60-day harvest interval.

\section{EFFECT OF SEASON OF THE YEAR}

Figure 3 shows that season of the year, largely as a result of rainfall, had a marked effect on forage production with maximum variations approximating 100 percent. Above-average yields were produced in May, June, July, and August, while low yields were produced during November, December, January, and February.

Protein content of the forage also varied markedly with season of the year ranging, with a 60 -day harvest interval and 800 pounds of nitrogen,

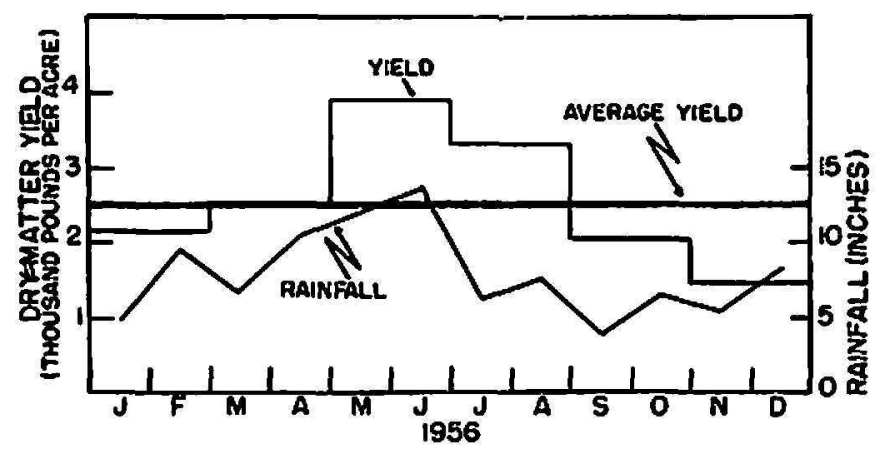

FIa. 3.-Effects of season of the year and rainfall on yield of Para grass cut every 60 days and fertilized with 800 pounds of nitrogen per acre yearly.

from as low as 7.4 to as high as 12.8 percent. In general, protein content was highest during seasons of low yields and vice versa.

\section{DISCUSSION}

Although highest yields were obtained when Para grass was cut every 90 days, the forage was of poor quality as indicated by the high lignin and relatively low protein and mineral contents. On the other hand, quality of the forage cut every 40 days was excellent. It is probably best to cut Para grass every 40 to 60 days, using the shorter interval during periods of fast growth.

The application of up to 800 pounds of nitrogen per acre yearly was profitable under the conditions of this experiment where rainfall was abundant, if the reasoning in the paper on Napier grass (first paper in this issue) is accepted. During dry years, the response to nitrogen fertilization will probably level off at about the 400-pound rate and higher rates should not be used during severe droughts, in order to avoid serious burning. 
With a 60-day harvest interval and 800 pounds of nitrogen per acre yearly, Para grass produced 30,841 pounds of dry forage, or about 70 tons of green forage, with 9.5 percent of protein. This is sufficient to meet the roughage requirements of about four mature cows or steers. It is of interest to note that similarly treated Para grass yielded 26,308 pounds of dry matter per acre yearly in still-unpublished experiments conducted by the authors on a steep Catalina clay in the mountain region.

The increase in lignin and decrease in protein and mineral contents with length of harvest interval is probably a normal result of maturity. The increase in protein content with nitrogen rates is to be expected, but the similar increase in lignin content is hard to explain. The decrease in phosphorus content with increasing nitrogen rates may have been caused by the dilution effect of higher yields in the presence of a relatively constant, limited amount of available phosphorus in the soil.

Rainfall was the main factor affecting seasonal growth of Para grass, although other factors such as day length and temperature were also apparently involved. The data suggest that seasonal variations in forage production could be reduced by using a longer harvest interval and heavier nitrogen fertilization during seasons of slow growth and a shorter harvest interval and lower nitrogen fertilization during seasons of fast growth. However, applications in excess of a rate equivalent to 400 pounds of nitrogen per acre yearly during dry periods can cause severe burning and loss of stand.

\section{SUMMARY}

The effects of rates ranging from 0 to 1,600 pounds of nitrogen per acre yearly and of 40-, 60-, and 90-day harvest intervals on the yield and composition of Para grass were determined over a 1 year period.

Yields increased with nitrogen fertilization up to the 800-pound level, while protein content and protein yields increased up to the 1,600-pound level.

About half of the fertilizer nitrogen was recovered in the forage when 800 pounds or less were applied per acre. Efficiency of utilization in terms of dry matter produced per pound of nitrogen, decreased rapidly with increasing rates.

The phosphorus content of the forage decreased while the lignin content increased with nitrogen rates. Nitrogen fertilization had no pronounced effect on the calcium, potassium, or magnesium contents of the forage.

Yields and lignin content of the forage increased while protein, phosphorus, calcium, magnesium, and potassium contents decreased with length of harvest interval.

There are marked seasonal variations in yield due primarily to rainfall. 
With a 60-day harvest interval and 800 pounds of nitrogen per acre yearly, Para grass yielded 30,841 pounds of dry forage, or about 70 tons of green forage, with a 9.5-percent protein content. With this treatment Para grass removed 52.4 pounds of $\mathrm{P}, 120$ of $\mathrm{Ca}, 524$ of $\mathrm{K}, 77 \mathrm{of} \mathrm{Mg}$, and 469 pounds of $\mathrm{N}$ per acre yearly. It is not advisable to use rates of more than 400 pounds of nitrogen per acre per year during dry weather.

\section{RESUMEN}

Se estudió el efecto de aplicaciones de nitrógeno que variaban entre 0 y 1,600 libras por cuerda por año, y de intervalos de corte de 40,60, y 90 días, en el rendimiento y composición de la yerba Pará (Panicum purpurascens).

Los rendimientos aumentaron con niveles de nitrógeno hasta 800 libras por cuerda por año. El contenido y rendimiento de proteína aumentó con niveles de nitrógeno hasta 1,600 libras por cuerda por año. Se recuperó en el forraje aproximadamente la mitad del nitrógeno aplicado hasta 800 libras por cuerda, pero la eficiencia de utilización expresada en términos de forraje seco producido por cada libra de nitrógeno disminuyó según se aumentaban los niveles de nitrógeno. El contenido de fósforo disminuyó, pero el de lignina aumentó al aumentar los niveles de nitrógeno. El contenido de calcio, potasio, y magnesio en el forraje no se afectó con las aplicaciones de nitrógeno.

Los rendimientos de forraje seco y el contenido de lignina aumentaron al alargarse los intervalos de corte. Sin embargo, el contenido de proteína, fósforo, calcio, magnesio, y potasio disminuyó segun se alargaron los intervalos de corte.

La producción varió considerablemente durante distintas épocas del an̄o.

Con un intervalo de corte de 60 días y 800 libras de nitrógeno por cuerda por año la yerba Pará produjo 30,841 libras de materia seca (como 70 toneladas de forraje verde) por cuerda por año, con un contenido de proteína de 9.5 por ciento. Con este tratamiento, la yerba extrajo 469 libras de nitrógeno, 524 libras de potassio, 120 libras de calcio, 77 libras de magnesio, y 52.4 libras de fósforo por cuerda por año. No debe aplicarse nitrógeno en más de 400 libras por acre al año en tiempo de sequía.

\section{LITERATURE CITED}

1. Rivera-Brenes, L., Technical and Economic Aspects of Roughage Production in Puerto Rico, Univ. P. R. Agr. Exp. Sta. Tech. Paper No. 12, 1953.

2. Rodriguez, J. P., Effect of nitrogen applications on the yield and composition of forage crops, J. Agr. Univ. P.R. 33(3) 98-117, 1949. 